\title{
Deactivation mechanism of the simultaneous removal of carbonyl sulphide and carbon disulphide over $\mathrm{Fe}-\mathrm{Cu}-\mathrm{Ni} / \mathrm{MCSAC}$ catalysts
}

\author{
KAI LI ${ }^{\mathrm{a}}, \mathrm{XIN}_{\mathrm{SONG}}{ }^{\mathrm{a}}, \mathrm{CHI}_{\mathrm{WANG}}^{\mathrm{b}}$, YI MEI ${ }^{\mathrm{b}}, \mathrm{XIN}^{\mathrm{SUN}}{ }^{\mathrm{a}}$ and PING NING ${ }^{\mathrm{a}, *}$ \\ ${ }^{a}$ Faculty of Environmental Science and Engineering, Kunming University of Science and Technology, Kunming \\ 650500, People's Republic of China \\ ${ }^{\mathrm{b}}$ Faculty of Chemical Engineering, Kunming University of Science and Technology, Kunming 650500, \\ People's Republic of China \\ E-mail: ningpingkmust@163.com
}

MS received 1 August 2017; revised 12 October 2017; accepted 12 October 2017; published online 10 November 2017

\begin{abstract}
The deactivation mechanism of the simultaneous removal of $\mathrm{COS}$ and $\mathrm{CS}_{2}$ over a $\mathrm{Fe}-\mathrm{Cu}-$ $\mathrm{Ni} / \mathrm{MCSAC}$ catalyst was investigated using SEM/EDS, XPS and in situ DRIFTS methods. The results show that the catalytic hydrolysis of $\mathrm{COS}$ and $\mathrm{CS}_{2}$ over the $\mathrm{Fe}-\mathrm{Cu}-\mathrm{Ni} / \mathrm{MCSAC}$ catalyst involves two steps: hydrolysis of COS/CS $\mathrm{CS}_{2}$ and oxidation of $\mathrm{H}_{2} \mathrm{~S}$. The SEM/EDS and XPS results indicate that that catalytic hydrolysis of $\mathrm{CS}_{2}$ can be achieved by the actions of alkaline groups and active components. When $\mathrm{O}_{2}$ was introduced into the system, oxidation of $\mathrm{H}_{2} \mathrm{~S}$ occurred $v i a \mathrm{H}_{2} \mathrm{~S} \rightarrow \mathrm{S} \rightarrow \mathrm{SO}_{4}^{2-}$ /sulphate. In situ DRIFTS experiments indicated that the formation of sulphate may occur as follows: (a) $\mathrm{H}_{2} \mathrm{~S}+\mathrm{O}_{2} \rightarrow \mathrm{S}+\mathrm{H}_{2} \mathrm{O}$, (b) $\mathrm{S}+\mathrm{O}_{2} \rightarrow \mathrm{S}-\mathrm{O}$, (c) $\mathrm{COO}+\mathrm{H}_{2} \mathrm{~S} \rightarrow-\mathrm{CH}+\mathrm{S}-\mathrm{O}$, (d) $\mathrm{C}-\mathrm{OH}+\mathrm{H}_{2} \mathrm{~S} \rightarrow-\mathrm{CH}+\mathrm{S}-\mathrm{O}$. The in situ DRIFTS experiments also indicated that the $\mathrm{C}-\mathrm{OH}$ groups, $-\mathrm{COO}$ groups and $\mathrm{O}_{2}$ played important roles in the deactivation of the catalyst, which was consistent with the XPS results. Meanwhile, the $\mathrm{SO}_{4}^{2-}$ / sulphate content increased during the reaction, which led to its occupancy of the catalyst's surface activity sites. Additionally, the alkaline groups and active components were removed, which could also result in the deactivation of the catalysts.
\end{abstract}

Keywords. Deactivation mechanism; simultaneous catalytic hydrolysis of $\mathrm{CS}_{2}$ and $\mathrm{COS} ; \mathrm{Fe}-\mathrm{Cu}-\mathrm{Ni} / \mathrm{MCSAC}$ catalyst; closed carbide furnace tail gas.

\section{Introduction}

As the by-products in the industrial production, such as closed carbide furnace tail gas, carbonyl sulphide $(\mathrm{COS})$ and carbon disulphide $\left(\mathrm{CS}_{2}\right)$ corrode pipeline equipment and influence the purity of the raw material gas. ${ }^{1-3}$ During various industrial productions, the presence of $\mathrm{COS}$ and $\mathrm{CS}_{2}$ negatively affects the performance of catalysts, reducing their activity and lifespan. ${ }^{4-6}$ To address this issue, catalytic hydrolysis has been shown to provide lower levels of by-products under mild reaction conditions and has thus become the most commonly used method to remove $\mathrm{COS}$ and $\mathrm{CS}_{2}$ from industrial processes. ${ }^{7-11}$ With the advantages of being cost-effective and having good adsorption, activated carbons have become a promising type of catalyst carrier. ${ }^{12-14}$ Several previous studies from our group have examined the hydrolysis of $\mathrm{COS}$ and $\mathrm{CS}_{2}$ over modified activated carbon catalysts. ${ }^{2,15-18}$ For example, we have shown that $\mathrm{Fe}-\mathrm{Cu}-\mathrm{Ni} / \mathrm{MCSAC}$ (i.e., microwave coconut shell activated carbons supported $\mathrm{Fe}_{2} \mathrm{O}_{3}, \mathrm{CuO}$ and $\mathrm{NiO}$ ) has a high catalytic hydrolysis activity and $100 \%$ COS conversion and $100 \% \mathrm{CS}_{2}$ conversion for approximately $540 \mathrm{~min}$ and $600 \mathrm{~min}$, respectively (reaction conditions: $400 \mathrm{ppm}$ COS; 10 ppm $\mathrm{CS}_{2}$; GHSV $\left.=10000 \mathrm{~h}^{-1}\right) .{ }^{17}$ However, its catalytic ability gradually decreased over the reaction time. Although the deactivation was attributed to the deposition of sulphur (S) on the catalyst's surface, the hydrolysis reaction and deactivation mechanisms remained unclear. ${ }^{17}$ Accordingly, these unresolved issues require further attention to improve the performance of the catalyst and its industrial application in the hydrolysis reaction.

\footnotetext{
*For correspondence

Electronic supplementary material: The online version of this article (https://doi.org/10.1007/s12039-017-1397-9) contains supplementary material, which is available to authorized users.
} 
Recently, many reports have detailed the hydrolysis reaction mechanism of COS and $\mathrm{CS}_{2}$. However, the results have varied for different catalysts and reaction paths. For instance, Guo et al., reported the COS hydrolysis mechanism without the use of a catalyst. ${ }^{19}$ The results indicated that $\mathrm{OH}$ and $\mathrm{H}$ in $\mathrm{H}_{2} \mathrm{O}$ first attack the $\mathrm{C}=\mathrm{O}$ and $\mathrm{C}=\mathrm{S}$ bonds in COS. In addition, Yi et $a l$., reported that the hydroxyl groups and oxygen free radicals on the catalyst's surface could enhance the catalytic performance for $\mathrm{CS}_{2} \cdot{ }^{20} \mathrm{Li}$ et al., also investigated the COS hydrolysis mechanism. The results indicated that the nucleophilic additions of water across the $\mathrm{C}=\mathrm{O}$ or $\mathrm{C}=\mathrm{S}$ bonds of $\mathrm{COS}$ were competitive. ${ }^{21}$ Further, Wang et al., investigated the reactivation of the catalyst for COS hydrolysis. The results demonstrated that the main source of the catalyst's strong basicity was the presence of alkaline ions. ${ }^{22}$ A study from the 1870 s on the hydrolysis of COS using a Co-Mo catalyst indicated that the catalyst's surface was partially covered by $-\mathrm{OH}$ and $\mathrm{H}_{2} \mathrm{O}$ and that $\mathrm{COS}$ was adsorbed on the catalyst's surface resulting in ion-dipole interactions. Moreover, the reaction centre was alkaline and played a key role in the COS hydrolysis reaction. ${ }^{23}$ Akimoto et al., reported that the catalyst would inactivate rapidly if strongly alkaline organic species were introduced to the reaction system. The results also indicated that COS would first become adsorbed at the active sites of the catalyst's surface and would then react with the adsorbed $\mathrm{H}_{2} \mathrm{O} .{ }^{24}$ Guanju Shang et al., demonstrated that the type of alkaline centre, alkaline strength and the number of alkaline functional groups all influence COS hydrolysis. ${ }^{25}$ In recent years, Hoggen et al., analysed the hydrolysis reaction of COS on the surface of $\gamma-\mathrm{Al}_{2} \mathrm{O}_{3}$ using FTIR analysis and quantum chemical calculations and obtained similar results. ${ }^{26}$ Wilson et al., studied the potential energy of the system surface and found that the rotatable $-\mathrm{OH}$ moieties provided hydrogen atoms for the close-in sulphur atom to generate hydrolysate $\left(\mathrm{CO}_{2}\right.$ and $\left.\mathrm{H}_{2} \mathrm{~S}\right) .{ }^{27}$ Hanaoka et al., studied the reaction mechanism of COS removal over activated carbon. The results showed that the activated carbon could eliminate $\mathrm{COS}$ and that some COS could be converted into $\mathrm{CO}_{2} \cdot{ }^{28}$ Additionally, the mechanism of $\mathrm{CS}_{2}$ hydrolysis is identical to that of COS, and COS is an intermediate the hydrolysis of $\mathrm{CS}_{2}$. Xiaofeng Guo et al., studied the adsorption process of $\mathrm{CS}_{2}$ on an $\mathrm{Al}_{2} \mathrm{O}_{3}$ catalyst with two possible outcomes: $\mathrm{CS}_{2}$ reacted directly with the adsorbed water on the surface of the catalyst, and $\mathrm{CS}_{2}$ generated the intermediate COS initially and then the COS reacted with $\mathrm{H}_{2} \mathrm{O}$. Therefore, the hydrolysis mechanism of $\mathrm{CS}_{2}$ may be summarized as $\mathrm{CS}_{2} \rightarrow \mathrm{COS} \rightarrow \mathrm{H}_{2} \mathrm{~S} \rightarrow$ $\mathrm{S} / \mathrm{SO}_{4}^{2-} \cdot{ }^{29}$
However, little research has focused on the deactivation mechanism of the simultaneous removal of $\mathrm{COS}$ and $\mathrm{CS}_{2}$. Our group has prepared a good catalyst $(\mathrm{Fe}-\mathrm{Cu}-\mathrm{Ni} / \mathrm{MCSAC})$ to simultaneously remove $\mathrm{COS}$ and $\mathrm{CS}_{2}$; however, the corresponding deactivation mechanism remains unknown. Determining the detailed steps of the deactivation mechanism is necessary because they can provide a theoretical foundation for the future application and development of the "simultaneous removal of $\mathrm{COS}$ and $\mathrm{CS}_{2}$ over $\mathrm{Fe}-\mathrm{Cu}-$ Ni/MCSAC" field. Therefore, this work characterizes the $\mathrm{Fe}-\mathrm{Cu}-\mathrm{Ni} / \mathrm{MCSAC}$ catalyst of deactivated samples under different conditions using SEM/EDS, XPS, in situ DRIFTS methods to investigate the deactivation mechanism of the simultaneous removal of COS and $\mathrm{CS}_{2}$.

\section{Experimental}

\subsection{Material preparation}

Microwave coconut shell activated carbon (MCSAC) was from the Faculty of Materials and Metallurgical Engineering, Kunming University of Science and Technology. The main preparation parameters: activation temperatures were 850 $900^{\circ} \mathrm{C}$, microwave processing time was $40 \mathrm{~min}$ and water vapour activation flow was $5 \mathrm{~g} / \mathrm{min}$. First, the MCSAC was crushed and sieved to a 40-60 mesh size and washed 5-7 times with tap water and then 5-7 times with distilled water to remove the suspended substances. The MSCAC was dried at $100^{\circ} \mathrm{C}$ for $3-5 \mathrm{~h}$ in a drying box and was then boiled in a $1 \mathrm{~mol} / \mathrm{L} \mathrm{KOH}$ solution for $2 \mathrm{~h}$. Subsequently, the MSCAC was washed with distilled water to a constant $\mathrm{pH}$ and then dried at $100^{\circ} \mathrm{C}$ for $3-5 \mathrm{~h}$ in a drying box.

$\mathrm{The} \mathrm{Fe}-\mathrm{Cu}-\mathrm{Ni} / \mathrm{MCSAC}$ catalyst was then prepared by the sol-gel method, which was similar to our previous reports. ${ }^{15-17}$ The MCSAC was impregnated in a colloid solution that contained $\mathrm{Fe}\left(\mathrm{NO}_{3}\right)_{3}, \mathrm{Cu}\left(\mathrm{NO}_{3}\right)_{2}, \mathrm{Ni}\left(\mathrm{NO}_{3}\right)_{2}$ and $\mathrm{Na}_{2} \mathrm{CO}_{3}$ in a $\mathrm{n}(\mathrm{Fe}): \mathrm{n}(\mathrm{Cu}): \mathrm{n}(\mathrm{Ni})$ molar fraction of 10:2:0.5. The sample was then ultrasonicated for $30 \mathrm{~min}$ and dried at $120^{\circ} \mathrm{C}$ for $3-4 \mathrm{~h}$ in a drying box. The sample was calcined at $300^{\circ} \mathrm{C}$ for $3 \mathrm{~h}$ under atmospheric conditions $(82.4 \mathrm{kPa})$ and then impregnated in a $13 \%$ (mass fraction) $\mathrm{KOH}$ solution under ultrasonic conditions for $30 \mathrm{~min}$ and dried at $120^{\circ} \mathrm{C}$ for 3-4 $\mathrm{h}$ in a drying box. The catalyst obtained after these procedures is designated as $\mathrm{Fe}-\mathrm{Cu}-\mathrm{Ni} / \mathrm{MCSAC}$.

\subsection{Material characterization}

A QUANTA200 scanning electron microscope was used in this work, which can observe the morphology changes of the catalysts. Beryllium (Be) was the metal probe, and the samples were pretreated by vacuum and gold plating methods. Energy dispersive X-ray spectrometry (EDS) was used to determine the chemical composition of the catalysts. An ESCALAB 250 X-ray photoelectron spectrometer 
from Thermo Fisher Scientific was used in this work. The resolution ratio is $0.45 \mathrm{eV}(\mathrm{Ag}), 0.82 \mathrm{eV}(\mathrm{PET})$, and the sensitivity is $180 \mathrm{kcps}(200 \mu \mathrm{m}, 0.5 \mathrm{eV})$ with an image resolution of $3 \mu \mathrm{m}$. In-situ DRIFTS were recorded on a Nicolet iS50 FTIR spectrometer equipped with a Smart Collector. Mass flow controllers and a sample temperature controller were used to simulate the reaction conditions. The IR spectra were recorded by accumulating $100 \mathrm{scans}$ at a resolution of $4 \mathrm{~cm}^{-1}$.

\subsection{Test of catalytic activity}

The desulfurization tests were performed in a fixed-bed quartz reactor under atmospheric pressure. $\mathrm{CS}_{2}$ and $\mathrm{COS}$ from a gas cylinder $\left(0.3 \% \mathrm{CS}_{2}\right.$ in $\mathrm{N}_{2} ; 1 \% \operatorname{COS}$ in $\mathrm{N}_{2} ;\left(\mathrm{O}_{2}: 99.999 \%\right.$, when used)) were diluted with $\mathrm{N}_{2}(99.99 \%)$ to the required concentration (i.e., $\mathrm{CS}_{2}: 30 \mathrm{mg} / \mathrm{m}^{3}$; COS: $980 \mathrm{mg} / \mathrm{m}^{3} ; \mathrm{O}_{2}$ content: $0-10.2 \%)$. The overall gas hourly space velocity (GHSV) was $18000 \mathrm{~h}^{-1}$. The water came from a saturator system in which the water temperature was $0.3-35^{\circ} \mathrm{C}$ and the corresponding relative humidity $(\mathrm{RH})$ was $17-96 \%$. The reaction temperature of the reactor was $30-70{ }^{\circ} \mathrm{C}$. The $\mathrm{CS}_{2}$ and COS concentrations in the mixture gas feed and effluent from this reactor were analysed using an HC-6 sulphur phosphorus microscale analyser. Figure S1 (in Supplementary Information) shows a schematic diagram of the apparatus for the catalytic activity measurements. The $\mathrm{CS}_{2}$ and COS removal rates were determined by calculating the inlet and outlet $\mathrm{CS}_{2}$ and $\mathrm{COS}$ concentrations:

$$
\begin{aligned}
& \mathrm{CS}_{2}(\mathrm{COS}) \text { removal rate }(\%) \\
& =\frac{\mathrm{CS}_{2}(\mathrm{COS})_{\text {in }}-\mathrm{CS}_{2}(\mathrm{COS})_{\text {out }}}{\mathrm{CS}_{2}(\mathrm{COS})_{\text {in }}} \times 100
\end{aligned}
$$

When the $\mathrm{CS}_{2}$ and COS conversions were below 90\%, the catalysts were regarded as being deactivated. The sulphur capacity was defined as the quantity of sulphur per unit mass of a catalyst (terminating at $90 \% \mathrm{CS}_{2}$ conversion and $90 \%$ COS conversion).

\section{Results and Discussion}

\subsection{SEM/EDS analysis}

The changes of the surface morphologies and elemental compositions can be observed by SEM/EDS. SEM images $(20000 \times$ and $5000 \times)$ of fresh and deactivated catalysts are presented in Figure 1 and the EDS results are presented in Table 1.

As seen, there were some metal oxides distributed on the surface. Most of the pores on the deactivated catalyst surface are blocked and there are relatively few pores on its surface (Figure 1c and Figure 1d). Meanwhile, there were more luminous white substances on the deactivated catalyst than on the fresh catalyst. Further, agglomeration was evident on the deactivated catalyst, suggesting a large amount of metal salt compounds on its surface, which blocked most of the pores, leading to deactivation.

EDS analyses of these catalysts were performed to illustrate the composition changes on the deactivated catalyst surface (Table 1). The mass fraction changes of $\mathrm{Na}, \mathrm{Fe}, \mathrm{Cu}$ and $\mathrm{Ni}$ were not obvious for the fresh and deactivated catalysts. However, the $\mathrm{S}$ content on the deactivated catalyst increased from $1.20 \%$ to $12.88 \%$, which can be attributed to the generation of elemental $\mathrm{S}$ or sulphate. These products can block the catalyst's pores and lead to a decrease of its specific area and lead to its deactivation. In contrast, the $\mathrm{C}$ content on the catalyst's surface decreased from $54.51 \%$ to $39.42 \%$, which can be attributed to the sulphate on the deactivated catalyst surface. In summary, the EDS analysis indicates that deactivation may occur because of the presence of sulphate on the catalyst's surface.

\subsection{XPS analysis}

\section{2a XPS analysis of fresh and deactivated catalysts:}

The elemental contents of the fresh and deactivated catalysts are shown in Table 1, and the XPS data of the catalysts are given in Figure 2 and Table 2.

$\mathrm{The} \mathrm{C}, \mathrm{Fe}, \mathrm{Cu}$, and $\mathrm{Ni}$ contents of the deactivated catalyst decreased compared with the fresh catalyst. The reason may be that metal oxides could be converted into some other metal sulphates or sulphites, and metal sulphates or sulphites could cover the catalyst's surface. The $\mathrm{S}$ content on the deactivated catalyst increased to $3.10 \%$, which we attribute to the formation of various sulphate substances.

As seen in Table 2, the $\mathrm{Fe}_{2}\left(\mathrm{SO}_{4}\right)_{3}$ content on the surface of deactivated catalyst increased, while the $\mathrm{Fe}_{2} \mathrm{O}_{3}$ content decreased from $1.04 \%$ to $0.79 \%$. The interactions between $\mathrm{H}_{2} \mathrm{~S}, \mathrm{O}_{2}, \mathrm{H}_{2} \mathrm{O}$ and $\mathrm{Fe}_{2} \mathrm{O}_{3}$ led to the decreasing and conversion of $\mathrm{Fe}_{2} \mathrm{O}_{3}$.

Compared with the deactivated catalyst, the $\mathrm{S}$ content of the fresh catalyst was not detected. The $\mathrm{S}$ chemical states on the deactivated catalyst varied. First, elemental $\mathrm{S}(163.95 \mathrm{eV})$ was only found on the deactivated catalyst, which was generated from the oxidation of $\mathrm{H}_{2} \mathrm{~S}$ in the presence of $\mathrm{O}_{2}$. Second, the peak at $168.83 \mathrm{eV}$ on the deactivated catalyst was obvious, which was attribute to $\mathrm{Fe}_{2}\left(\mathrm{SO}_{4}\right)_{3} /$ sulphate. This peak indicates that $\mathrm{H}_{2} \mathrm{~S}$ can be oxidized to $\mathrm{Fe}_{2}\left(\mathrm{SO}_{4}\right)_{3} /$ sulphate.

\section{2b XPS analysis of deactivated catalysts at different} $\mathrm{O}_{2}$ contents: The above analysis of fresh and deactivated catalysts indicates that the deactivated catalysts surface is covered by $\mathrm{S}$ and sulphate species. Clearly, oxidation plays a critical role in the process, and changing the $\mathrm{O}_{2}$ content may lead to differences in the type 


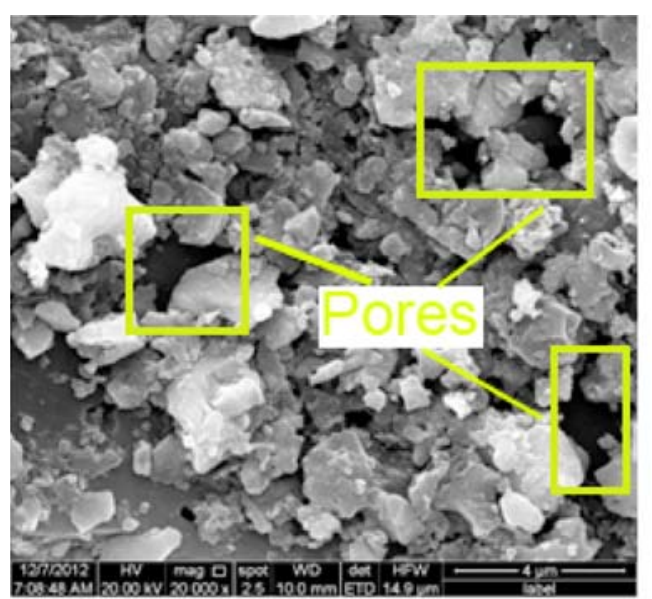

(a) $20000 \times$

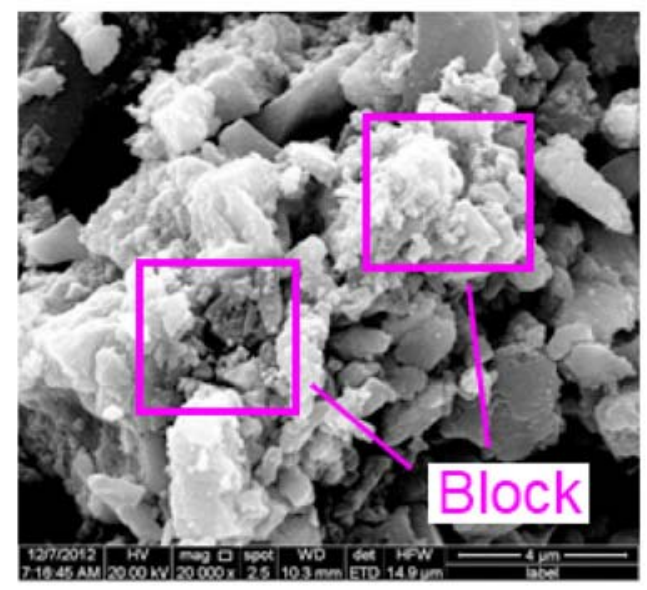

(c) $20000 \times$

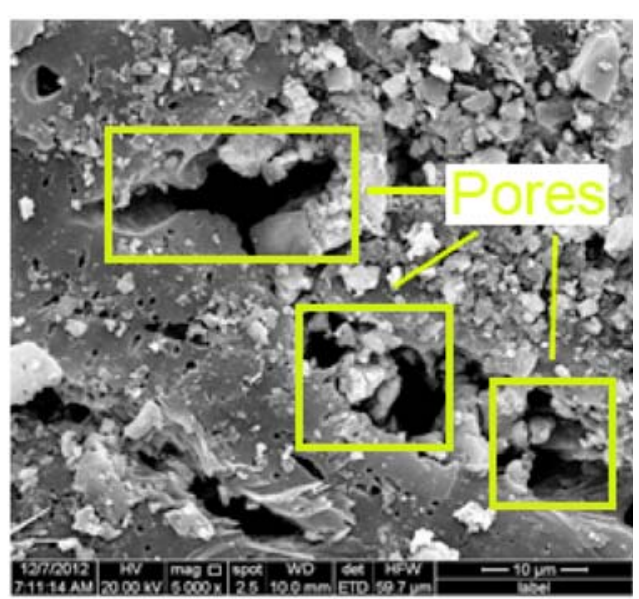

(b) $5000 \times$

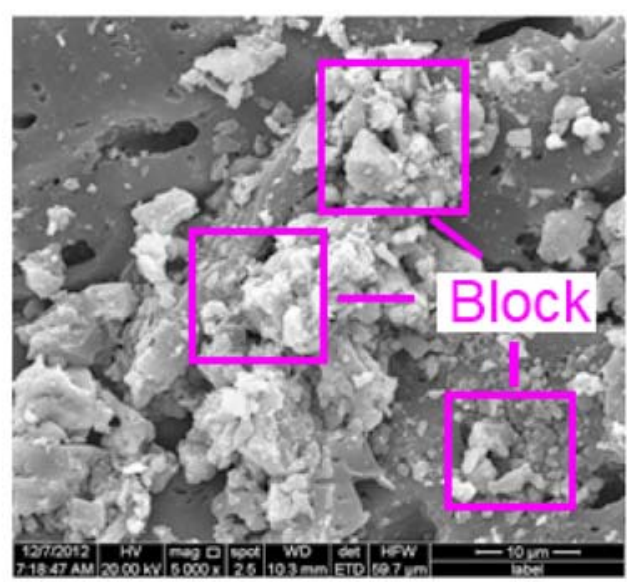

(d) $5000 \times$

Figure 1. SEM images of fresh $\mathrm{Fe}-\mathrm{Cu}-\mathrm{Ni} / \mathrm{MCSAC}$ (a: $20000 \times$; b: $5000 \times$ ) and deactivated $\mathrm{Fe}-\mathrm{Cu}-\mathrm{Ni} / \mathrm{MCSAC}(\mathrm{c}: 20000 \times$; d: $5000 \times$ ). (a) $20000 \times$ (b) $5000 \times$ (c) $20000 \times$ (d) $5000 \times$.

Table 1. EDS and XPS results of fresh and deactivated catalysts.

\begin{tabular}{|c|c|c|c|c|c|}
\hline \multirow[t]{2}{*}{ Element } & \multicolumn{2}{|c|}{$\begin{array}{l}\text { Element content (mass } \\
\text { fraction) } / \% \text { in EDS results }\end{array}$} & \multirow[t]{2}{*}{ Element } & \multicolumn{2}{|c|}{$\begin{array}{l}\text { Element content (atom } \\
\text { fraction) } / \% \text { in XPS results }\end{array}$} \\
\hline & Fresh catalyst & Deactivated catalyst & & Fresh catalyst & Deactivated catalyst \\
\hline $\mathrm{C}$ & 54.51 & 39.42 & $\mathrm{C}$ & 75.84 & 74.18 \\
\hline $\mathrm{O}$ & 12.80 & 14.86 & $\mathrm{O}$ & 20.69 & 20.32 \\
\hline $\mathrm{Na}$ & 3.47 & 3.77 & $\mathrm{Fe}$ & 1.04 & 0.79 \\
\hline $\mathrm{S}$ & 1.20 & 12.88 & $\mathrm{~S}$ & 0.00 & 3.10 \\
\hline $\mathrm{K}$ & 11.73 & 12.02 & $\mathrm{Cu}$ & 0.34 & 0.26 \\
\hline $\mathrm{Fe}$ & 12.59 & 12.88 & $\mathrm{Ni}$ & 0.15 & 0.14 \\
\hline $\mathrm{Ni}$ & 1.10 & 1.54 & $\mathrm{~N}$ & 1.54 & 1.21 \\
\hline $\mathrm{Cu}$ & 2.60 & 2.63 & & & \\
\hline
\end{tabular}

of products generated. Figure S2 (in Supplementary Information) shows the effect of the $\mathrm{O}_{2}$ content on the simultaneous catalytic hydrolysis of COS and $\mathrm{CS}_{2}$. As shown in Figure S2a, the conversion efficiency of COS decreased as the $\mathrm{O}_{2}$ content increased. Figure $\mathrm{S} 2 \mathrm{~b}$ shows that the conversion efficiency of $\mathrm{CS}_{2}$ initially increased but then decreased as the $\mathrm{O}_{2}$ content increased. Further, the sulphur capacity was highest $(57.33 \mathrm{mgS} / \mathrm{g})$ when the $\mathrm{O}_{2}$ content was $0 \%$ (Figure $\mathrm{S} 2 \mathrm{c}$ ). The sulphate capacity decreased with an increase in $\mathrm{O}_{2}$, and the sulphate 

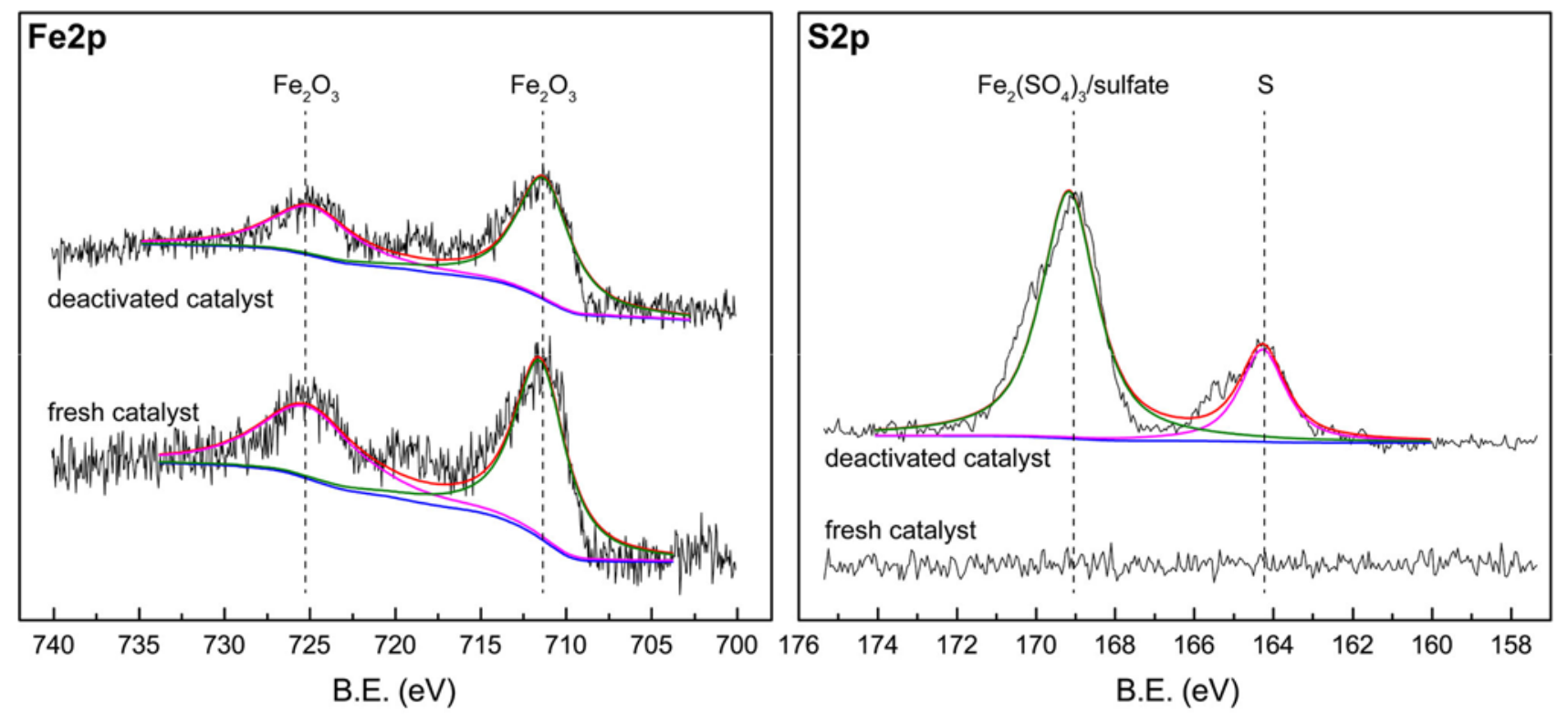

Figure 2. XPS characterization of the fresh catalyst and deactivated catalysts (Fe2p, S2p).

Table 2. XPS data of the fresh and deactivated catalysts (Fe2p, S2p).

\begin{tabular}{lcccc}
\hline Catalyst & Elements & Binding Energy $(\mathrm{eV})$ & At. \% & Chemical Speciation \\
\hline Fresh catalyst & $\mathrm{Fe} 2 \mathrm{p}$ & 711.42 & 1.04 & $\mathrm{Fe}_{2} \mathrm{O}_{3}$ \\
& $\mathrm{~S} 2 \mathrm{p}$ & - & - & - \\
Deactivated catalyst & $\mathrm{Fe2p}$ & 711.46 & 0.79 & $\mathrm{Fe}_{2} \mathrm{O}_{3}$ \\
& $\mathrm{~S} 2 \mathrm{p}$ & 163.95 & 0.73 & $\mathrm{~S}$ \\
& & 168.83 & 2.37 & $\mathrm{Fe}_{2}\left(\mathrm{SO}_{4}\right)_{3} /$ Sulphate \\
\hline
\end{tabular}

capacity remained above $45 \mathrm{mgS} / \mathrm{g}$ when the $\mathrm{O}_{2}$ content was $3.6 \%$, which indicates that the catalyst can function in an environment with a small amount of $\mathrm{O}_{2}$.

XPS analyses of the deactivated catalysts at $2.2 \%$ and $10.2 \% \mathrm{O}_{2}$ content are presented in Figure 3 and Table 3.

There is a clear difference in the XPS data of $\mathrm{Fe} 2 \mathrm{p}$ between the deactivated catalysts at $2.2 \%$ and $10.2 \% \mathrm{O}_{2}$ contents. The $\mathrm{Fe}_{2} \mathrm{O}_{3}$ content on the catalyst at an $\mathrm{O}_{2}$ content of $10.2 \%$ decreased from $0.79 \%$ to $0.63 \%$ compared with the sample at an $\mathrm{O}_{2}$ content of $2.2 \%$, which indicates that most of the $\mathrm{Fe}_{2} \mathrm{O}_{3}$ participated in the oxidation of $\mathrm{H}_{2} \mathrm{~S}$, especially at high $\mathrm{O}_{2}$ content.

Compared with the elemental S content on the catalyst at $2.2 \% \mathrm{O}_{2}$ content $(0.29 \%)$, the elemental $\mathrm{S}$ content on the catalyst at $10.2 \% \mathrm{O}_{2}$ content was low $(0.08 \%)$. Clearly, a high $\mathrm{O}_{2}$ content leads to the oxidation of elemental $\mathrm{S}$ to sulphate. We assign the peak at approximately $169.64 \mathrm{eV}$ to $\mathrm{Fe}_{2}\left(\mathrm{SO}_{4}\right)_{3}$ /sulphate. It is clear that the $\mathrm{Fe}_{2}\left(\mathrm{SO}_{4}\right)_{3} /$ sulphate content on the catalyst at an $\mathrm{O}_{2}$ content of $10.2 \%$ is higher than it is on the catalyst at an $\mathrm{O}_{2}$ content of $2.2 \%$. On one hand, the high $\mathrm{O}_{2}$ content promotes the oxidation of $\mathrm{H}_{2} \mathrm{~S}$; on the other hand, elemental $\mathrm{S}$ derived from the oxidation of $\mathrm{H}_{2} \mathrm{~S}$ can be converted into sulphate more quickly under a high $\mathrm{O}_{2}$ content. Thus, the increase of $\mathrm{H}_{2} \mathrm{~S}$ oxidation and fast generation of $\mathrm{Fe}_{2}\left(\mathrm{SO}_{4}\right)_{3}$ /sulphate occurs, which is consistent with previous conclusions. FeS and $\mathrm{CuS}$ may be formed during the reaction process, but because of the existing of $\mathrm{O}_{2}$ and $\mathrm{H}_{2} \mathrm{O}$ in the reaction system, $\mathrm{FeS}$ and $\mathrm{CuS}$ could be turned to the metal sulphates or sulfites. The $\mathrm{Fe}_{2}\left(\mathrm{SO}_{4}\right)_{3} /$ Sulphate could be found from the XPS results. Furthermore, the contents of $\mathrm{Cu}$ was so low that it was difficult to find the $\mathrm{Cu}_{2}\left(\mathrm{SO}_{4}\right)_{3} /$ Sulphate. Besides, the stability of metal carbonate is poor, so the metal sulphates or sulfites could be generated more easily than metal carbonate under the condition of sulfate radical existing. Thus, metal carbonate could not be detected from XPS results.

\section{2c XPS analysis of deactivated catalysts at differ-} ent $R H$ : The previous section describes the changes of the surface species on the catalyst as a function of $\mathrm{O}_{2}$ content. Water is a reactant in catalytic hydrolysis, so relative humidity $(\mathrm{RH})$ is an important factor in this process. Figure S3 (in Supplementary Information) shows 

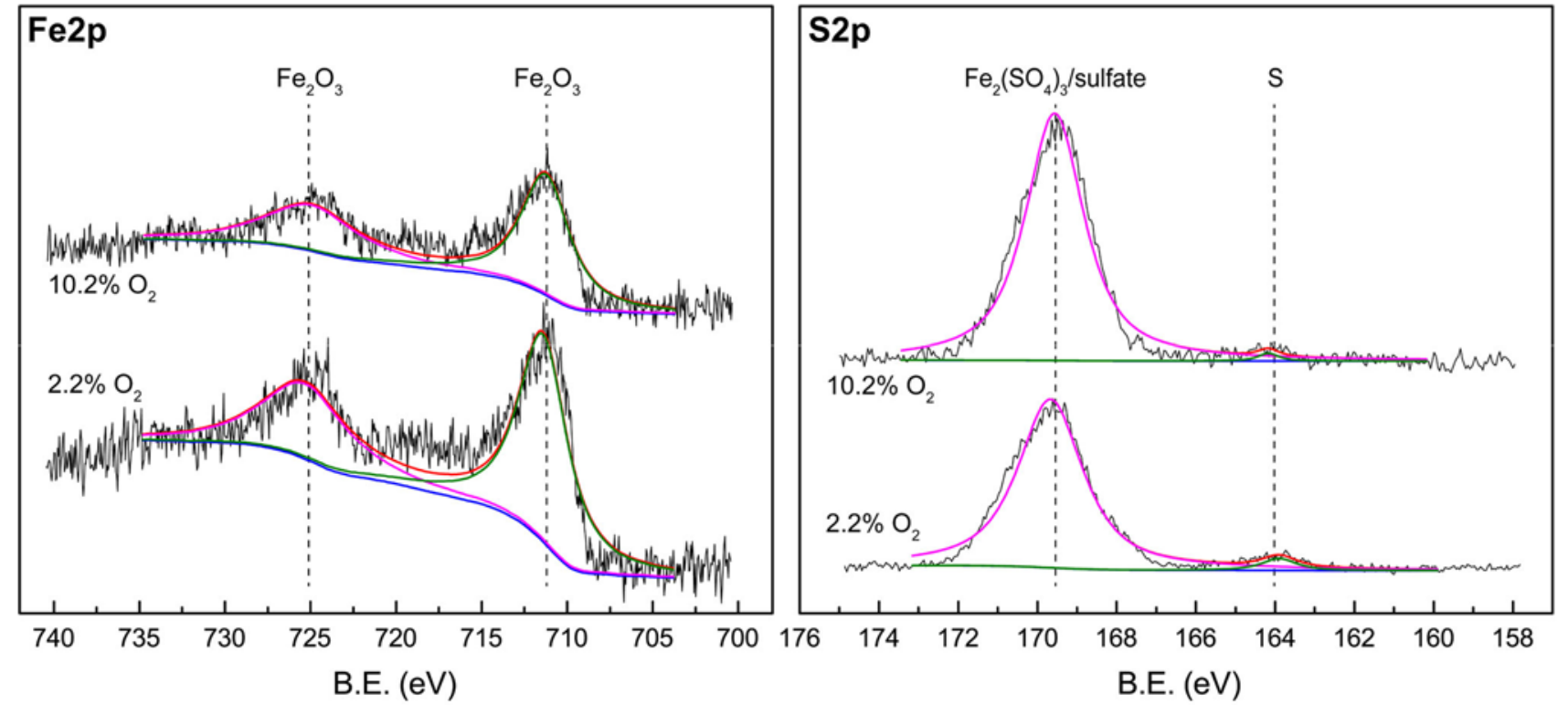

Figure 3. XPS characterization of the deactivated catalysts at $2.2 \%$ and $10.2 \% \mathrm{O}_{2}$ contents $(\mathrm{Fe} 2 \mathrm{p}, \mathrm{S} 2 \mathrm{p})$.

Table 3. XPS data of the deactivated catalysts at $2.2 \%$ and $10.2 \% \mathrm{O}_{2}$ content (Fe2p, S2p).

\begin{tabular}{lcccc}
\hline Catalyst & Elements & Binding Energy $(\mathrm{eV})$ & At. \% & Chemical Speciation \\
\hline Deactivated catalyst $\left(2.2 \% \mathrm{O}_{2}\right)$ & $\mathrm{Fe} 2 \mathrm{p}$ & 711.37 & 0.79 & $\mathrm{Fe}_{2} \mathrm{O}_{3}$ \\
& $\mathrm{~S} 2 \mathrm{p}$ & 164.01 & 0.29 & $\mathrm{~S}$ \\
& & 169.64 & 0.96 & $\mathrm{Fe}_{2}\left(\mathrm{SO}_{4}\right)_{3} / \mathrm{Sulphate}$ \\
Deactivated catalyst $\left(10.2 \% \mathrm{O}_{2}\right)$ & $\mathrm{Fe} 2 \mathrm{p}$ & 711.39 & 0.63 & $\mathrm{Fe}_{2} \mathrm{O}_{3}$ \\
& $\mathrm{~S} 2 \mathrm{p}$ & 164.09 & 0.08 & $\mathrm{~S}$ \\
& & 169.67 & 1.26 & $\mathrm{Fe}_{2}\left(\mathrm{SO}_{4}\right)_{3} / \mathrm{Sulphate}$ \\
\hline
\end{tabular}

the effect of RH on the simultaneous catalytic hydrolysis of COS and $\mathrm{CS}_{2}$. As seen in Figure S3a and Figure $\mathrm{S} 3 \mathrm{~b}$, the conversion efficiency of $\mathrm{CS}_{2}$ and COS initially increased but then decreased as the RH increased, and the highest catalytic efficiency was achieved when the $\mathrm{RH}$ was $32 \%$. Excess $\mathrm{H}_{2} \mathrm{O}$ may compete with $\mathrm{COS}$ and $\mathrm{CS}_{2}$ for adsorption sites, which decreased the hydrolysis efficiency. ${ }^{30}$ Meanwhile, excess $\mathrm{H}_{2} \mathrm{O}$ led to the formation of a water film, which may inhibit the diffusion and adsorption of COS and $\mathrm{CS}_{2}$ on the catalyst's surface. ${ }^{30}$ As seen in Figure S3c, the sulphur capacity initially increased but then decreased as the RH increased, and it was highest $(63.5 \mathrm{mgS} / \mathrm{g})$ when the RH was $32 \%$. Further, the sulphate capacity remained above $60 \mathrm{mgS} / \mathrm{g}$ when the RH was $17 \%-49 \%$, which indicates that the RH range was favourable for catalytic activity.

The XPS results of the deactivated catalysts at $0 \%$ and $96 \%$ RH are presented in Figure 4 and Table 4.

There is a difference in the XPS data of $\mathrm{Fe} 2 \mathrm{p}$ for the catalysts at $0 \%$ and $96 \% \mathrm{RH}$. The $\mathrm{Fe}_{2} \mathrm{O}_{3}$ content on the catalysts at $96 \% \mathrm{RH}$ was low. The reason may be that the water film affected the reaction and $\mathrm{Fe}_{2} \mathrm{O}_{3}$ was decreased and converted. More water film was produced on the catalyst's surface when the RH was $96 \%$ and inhibited the hydrolysis reaction. It indicates that excessive water film was not conductive to the hydrolysis of $\mathrm{COS} / \mathrm{CS}_{2}$.

Compared with the $\mathrm{Fe} 2 \mathrm{p}$ changes, the changes of S2p were complex. We assign the peak at approximately 163.28 and $164.11 \mathrm{eV}$ to elemental S. The S content on the catalyst at $96 \%$ RH was low, as elemental $\mathrm{S}$ could be more easily oxidized to sulphate at this $\mathrm{RH}$. We assign the peak at approximately $168.67 \mathrm{eV}$ to $\mathrm{Fe}_{2}\left(\mathrm{SO}_{4}\right)_{3}$ /sulphate. Clearly, the $\mathrm{Fe}_{2}\left(\mathrm{SO}_{4}\right)_{3} /$ sulphate content on the catalyst at $96 \%$ RH was higher than the other sulphur species. At high $\mathrm{RH}(96 \%), \mathrm{H}_{2} \mathrm{O}$ can provide $\mathrm{O}$ free radicals, which would promote the oxidation of $\mathrm{H}_{2} \mathrm{~S}$ and the formation of $\mathrm{Fe}_{2}\left(\mathrm{SO}_{4}\right)_{3} /$ sulphate. These results agree with the changes of $\mathrm{S}$. Therefore, the oxidation products of $\mathrm{H}_{2} \mathrm{~S}$ were relatively more at high $\mathrm{RH}$ $(96 \%)$.

3.2d XPS analysis of deactivated catalysts at different inlet concentrations: The inlet concentration has a 

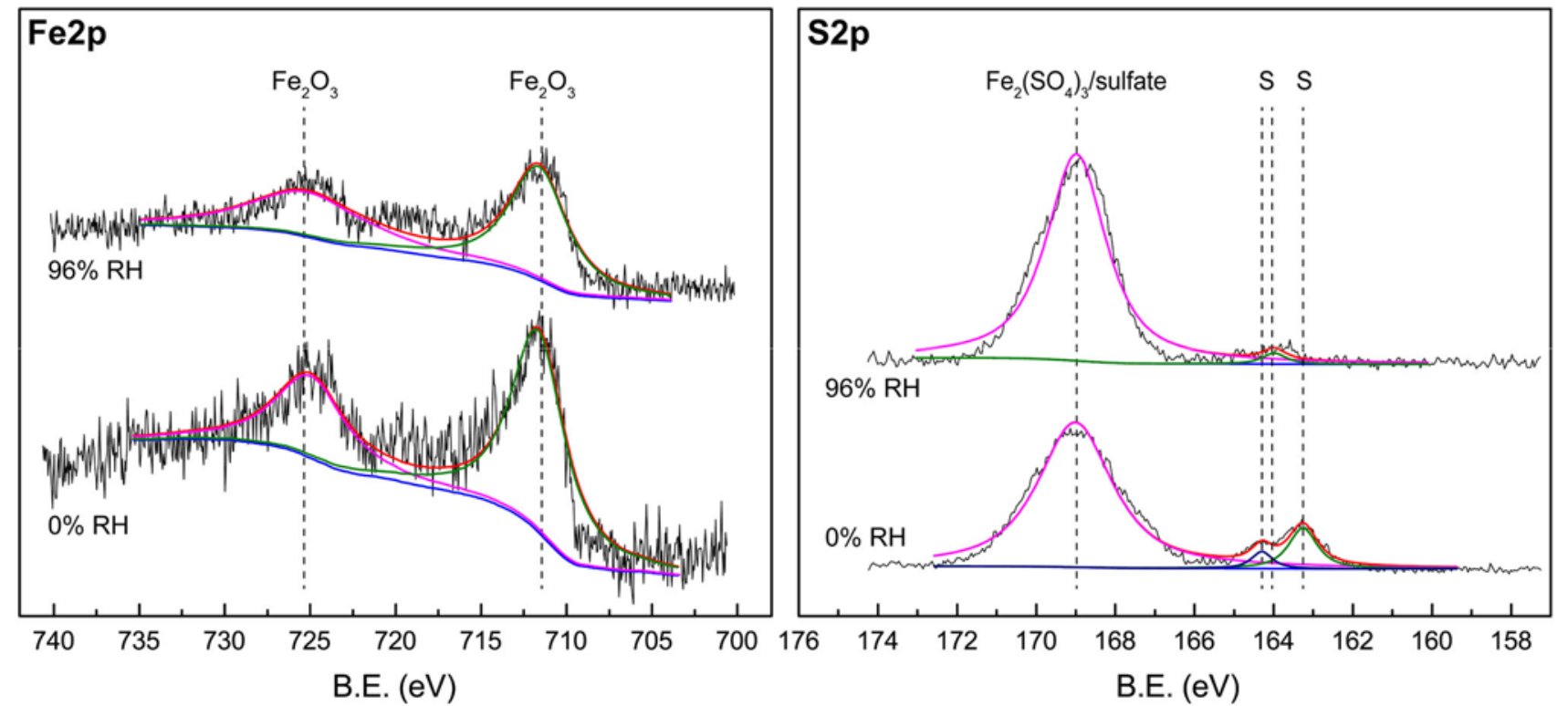

Figure 4. XPS characterization of the deactivated catalyst at $0 \% \mathrm{RH}$ and $96 \% \mathrm{RH}(\mathrm{Fe} 2 \mathrm{p}, \mathrm{S} 2 \mathrm{p})$.

Table 4. XPS data of the deactivated catalysts at $0 \%$ and $96 \% \mathrm{RH}(\mathrm{Fe} 2 \mathrm{p}, \mathrm{S} 2 \mathrm{p})$.

\begin{tabular}{lcccc}
\hline Catalyst & Elements & Binding Energy (eV) & At. \% & Chemical Speciation \\
\hline Deactivated catalyst (0\% RH) & $\mathrm{Fe} 2 \mathrm{p}$ & 711.32 & 0.77 & $\mathrm{Fe}_{2} \mathrm{O}_{3}$ \\
& $\mathrm{~S} 2 \mathrm{p}$ & 163.28 & 0.03 & $\mathrm{~S}$ \\
& & 164.11 & 0.07 & $\mathrm{~S}$ \\
& & 168.67 & 0.92 & $\mathrm{Fe}_{2}\left(\mathrm{SO}_{4}\right)_{3} / \mathrm{Sulphate}$ \\
& $\mathrm{Fe} 2 \mathrm{p}$ & 711.41 & 0.58 & $\mathrm{Fe}_{2} \mathrm{O}_{3}$ \\
& $\mathrm{~S} 2 \mathrm{p}$ & 164.06 & 0.02 & $\mathrm{~S}$ \\
& & 168.98 & 1.65 & $\mathrm{Fe}_{2}\left(\mathrm{SO}_{4}\right)_{3} / \mathrm{Sulphate}$ \\
\hline
\end{tabular}

clear effect on the hydrolysis process. Figure S4 (in Supplementary Information) shows the effect of the inlet concentration ratio of $\mathrm{COS} / \mathrm{CS}_{2}$ on the simultaneous catalytic hydrolysis of $\mathrm{COS}$ and $\mathrm{CS}_{2}$. As seen in Figure $\mathrm{S} 4 \mathrm{a}$ and Figure $\mathrm{S} 4 \mathrm{~b}$, the conversion efficiency of COS and $\mathrm{CS}_{2}$ decreased as the $\mathrm{COS} / \mathrm{CS}_{2}$ ratio decreased. This result suggests that the $\mathrm{CS}_{2}$ increase inhibits the catalytic activity of the catalyst when the total concentration of $\mathrm{COS}$ and $\mathrm{CS}_{2}$ is constant. Additionally, Figure $\mathrm{S} 4 \mathrm{c}$ shows that the sulphur capacity decreased as the $\mathrm{COS} / \mathrm{CS}_{2}$ decreased. One of the reasons for these results may be that the hydrolysis of $\mathrm{CS}_{2}$ is the rate-limiting step. Indeed, COS is a type of intermediate product in the hydrolysis of $\mathrm{CS}_{2}$, and low $\mathrm{COS} / \mathrm{CS}_{2}$ may produce more $\mathrm{COS}$, which decreases the catalytic activity. Further, low $\mathrm{COS} / \mathrm{CS}_{2}$ may produce more $\mathrm{H}_{2} \mathrm{~S}$ and sulphate, which may block the active sites and decrease the catalytic activity. To examine these issues more fully, XPS analyses of deactivated catalysts at 1:1 and 1:40 $\mathrm{CS}_{2} / \mathrm{COS}$ content were performed and are presented in Figure 5 and Table 5.
There are two different peaks between the catalyst at 1:1 and 1:40 $\mathrm{CS}_{2} / \mathrm{COS}$ content in the XPS data of O1s. The peak at approximately $531.58 \mathrm{eV}$ belongs to the $\mathrm{C}=\mathrm{O}$ bond, and its content on the catalyst at $1: 1 \mathrm{CS}_{2} / \mathrm{COS}$ content was clearly higher than that at the 1:40 $\mathrm{CS}_{2} / \mathrm{COS}$ content. A large number of COS intermediates generated from the hydrolysis at high $\mathrm{CS}_{2}$ concentration did not fully participate in the hydrolysis reaction. It is possible that the $\mathrm{C}=\mathrm{O}$ bonds became adsorbed on the catalyst's surface and led to the deactivation of the catalyst. The peak at approximately 533.37 $\mathrm{eV}$ belongs to the $-\mathrm{COOH}$ bond, and its content on the catalyst at $1: 1 \mathrm{CS}_{2} / \mathrm{COS}$ was slightly lower than it was at $1: 40 \mathrm{CS}_{2} / \mathrm{COS}$. We attribute this difference to the lack of $\mathrm{H}_{2} \mathrm{O}$ that could react with a high concentration of COS. Thus, more - $\mathrm{OH}$ free radicals were generated from the cleavage of the $-\mathrm{COOH}$ bond when the $\mathrm{CS}_{2} / \mathrm{COS}$ ratio was 1:1.

There was a difference between the catalyst at 1:1 and 1:40 $\mathrm{CS}_{2} / \mathrm{COS}$ in the XPS data of Fe2p. The peak at approximately $711.43 \mathrm{eV}$ belongs to $\mathrm{Fe}_{2} \mathrm{O}_{3}$. Clearly, 

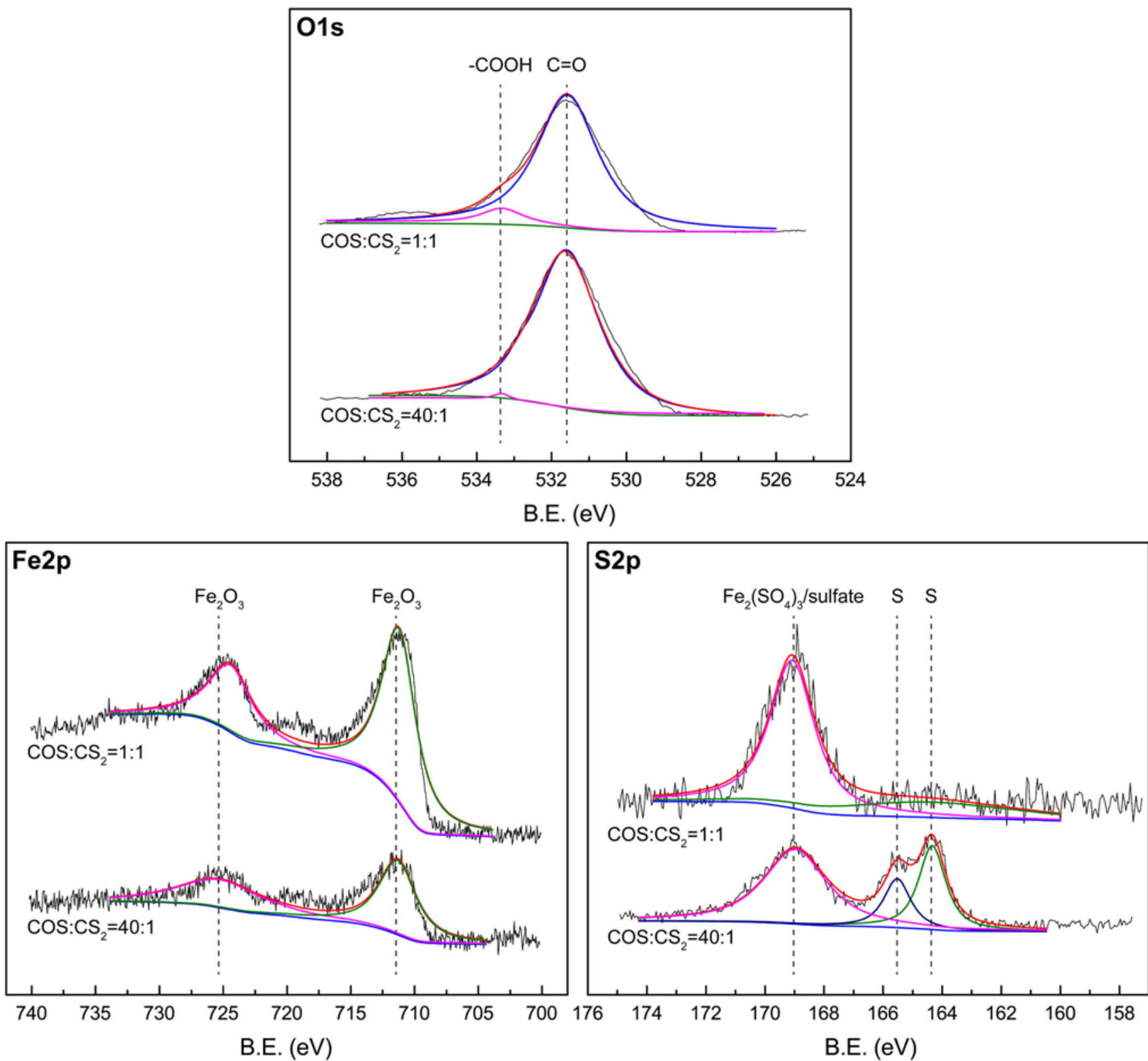

Figure 5. XPS characterization of the deactivated catalyst at a 40:1 COS/CS 2 content and a 1:1 COS/CS 2 content $(\mathrm{O} 1 \mathrm{~s}$, Fe2p, S2p).

Table 5. XPS data of the deactivated catalysts at 40:1 and 1:1 COS/CS 2 content (Fe2p, S2p).

\begin{tabular}{|c|c|c|c|c|}
\hline Catalyst & Elements & Binding Energy (eV) & At. $\%$ & Chemical Speciation \\
\hline \multirow[t]{6}{*}{ Deactivated catalyst $\left(40: 1 \mathrm{COS} / \mathrm{CS}_{2}\right)$} & \multirow[t]{2}{*}{$\mathrm{O} 1 \mathrm{~s}$} & 531.58 & 15.87 & $\mathrm{C}=\mathrm{O}$ bond \\
\hline & & 533.37 & 3.35 & $-\mathrm{COOH}$ bond \\
\hline & \multirow{2}{*}{$\mathrm{Fe} 2 \mathrm{p}$} & 711.43 & 0.45 & $\mathrm{Fe}_{2} \mathrm{O}_{3}$ \\
\hline & & 164.16 & 0.41 & $\mathrm{~S}$ \\
\hline & \multirow[t]{2}{*}{ S2p } & 165.37 & 0.25 & $\mathrm{~S}$ \\
\hline & & 169.19 & 0.59 & $\mathrm{Fe}_{2}\left(\mathrm{SO}_{4}\right)_{3} /$ Sulphate \\
\hline \multirow{5}{*}{ Deactivated catalyst $\left(1: 1 \mathrm{COS} / \mathrm{CS}_{2}\right)$} & \multirow[t]{2}{*}{$\mathrm{O} 1 \mathrm{~s}$} & 531.60 & 30.89 & $\mathrm{C}=\mathrm{O}$ bond \\
\hline & & 533.39 & 1.92 & $-\mathrm{COOH}$ bond \\
\hline & $\mathrm{Fe} 2 \mathrm{p}$ & 711.45 & 0.79 & $\mathrm{Fe}_{2} \mathrm{O}_{3}$ \\
\hline & \multirow{2}{*}{$\mathrm{S} 2 \mathrm{p}$} & 164.22 & 0.03 & $\mathrm{~S}$ \\
\hline & & 169.12 & 1.26 & $\mathrm{Fe}_{2}\left(\mathrm{SO}_{4}\right)_{3} /$ Sulphate \\
\hline
\end{tabular}


its content on the catalyst at $1: 1 \mathrm{CS}_{2} / \mathrm{COS}$ was higher than it was at 1:40 $\mathrm{CS}_{2} / \mathrm{COS}$. These results indicate that a high $\mathrm{COS}$ content promotes the conversion of $\mathrm{Fe}_{2} \mathrm{O}_{3}$.

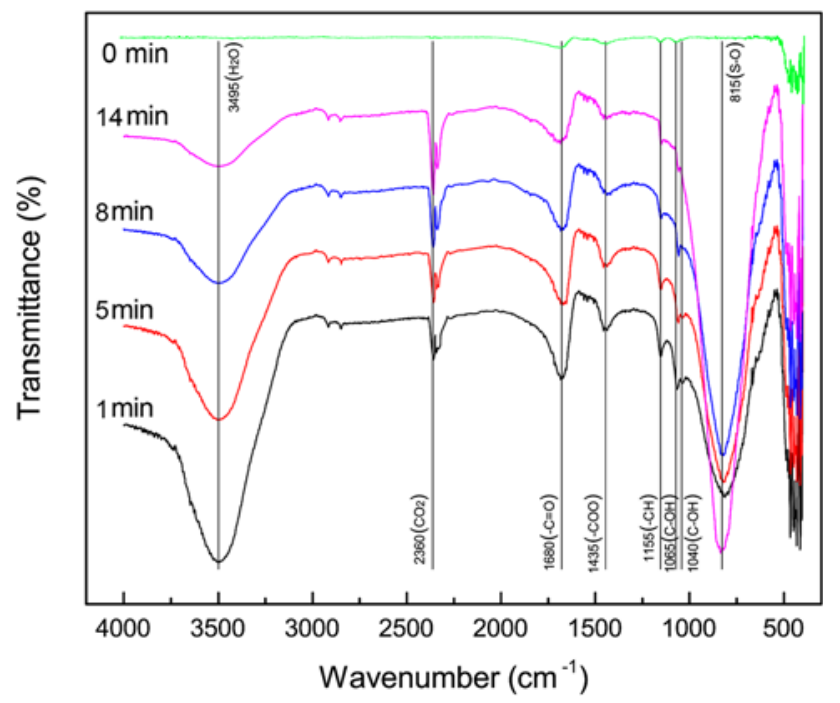

Figure 6. In situ DRIFTS experiment over the catalyst (Reaction temperature $=50^{\circ} \mathrm{C} ; \quad \mathrm{RH}=49 \%$; $\mathrm{O}_{2}=0.5 \% ; \mathrm{GHSV}=20000 \mathrm{~h}^{-1} ; \mathrm{CS}_{2}=30 \mathrm{mg} / \mathrm{m}^{3}$; $\left.\operatorname{COS}=980 \mathrm{mg} / \mathrm{m}^{3}\right)$.
Compared with the changes of O1s and Fe2p, the changes of S2p were complex, and the types of S2p on the two catalysts are not completely similar. We assign the peak at approximately 164.16 and $165.37 \mathrm{eV}$ to elemental S. Its content on the catalyst at $1: 1 \mathrm{CS}_{2} / \mathrm{COS}$ was clearly lower than it was at 1:40 $\mathrm{CS}_{2} / \mathrm{COS}$, which may result from it being oxidized to other intermediate products or sulphate. We assign the peak at approximately $169.19 \mathrm{eV}$ to $\mathrm{Fe}_{2}\left(\mathrm{SO}_{4}\right)_{3} /$ sulphate. The total sulphate content on the catalyst at $1: 1 \mathrm{CS}_{2} / \mathrm{COS}$ was higher than it was on the catalyst at 1:40 $\mathrm{CS}_{2} / \mathrm{COS}$. Meanwhile, the $\mathrm{Fe}_{2}\left(\mathrm{SO}_{4}\right)_{3} /$ sulphate species on the catalyst at $1: 1$ $\mathrm{CS}_{2} / \mathrm{COS}$ were more because the metal oxides participated in the reaction and produced different types of sulphates.

\subsection{In situ DRIFTS results}

To better understand the hydrolysis reaction and investigate the hydrolysis reaction mechanism, in situ DRIFTS experiments were performed to show the change of the surface functional groups in the hydrolysis reaction of $\mathrm{COS}$ and $\mathrm{CS}_{2}$ over the $\mathrm{Fe}-\mathrm{Cu}-\mathrm{Ni} / \mathrm{MCSAC}$ catalyst. As seen in Figure 6, there were a small amount of $\mathrm{C}=\mathrm{O}$ groups, $-\mathrm{COO}$ groups, $-\mathrm{CH}$ groups and $\mathrm{C}-\mathrm{OH}$
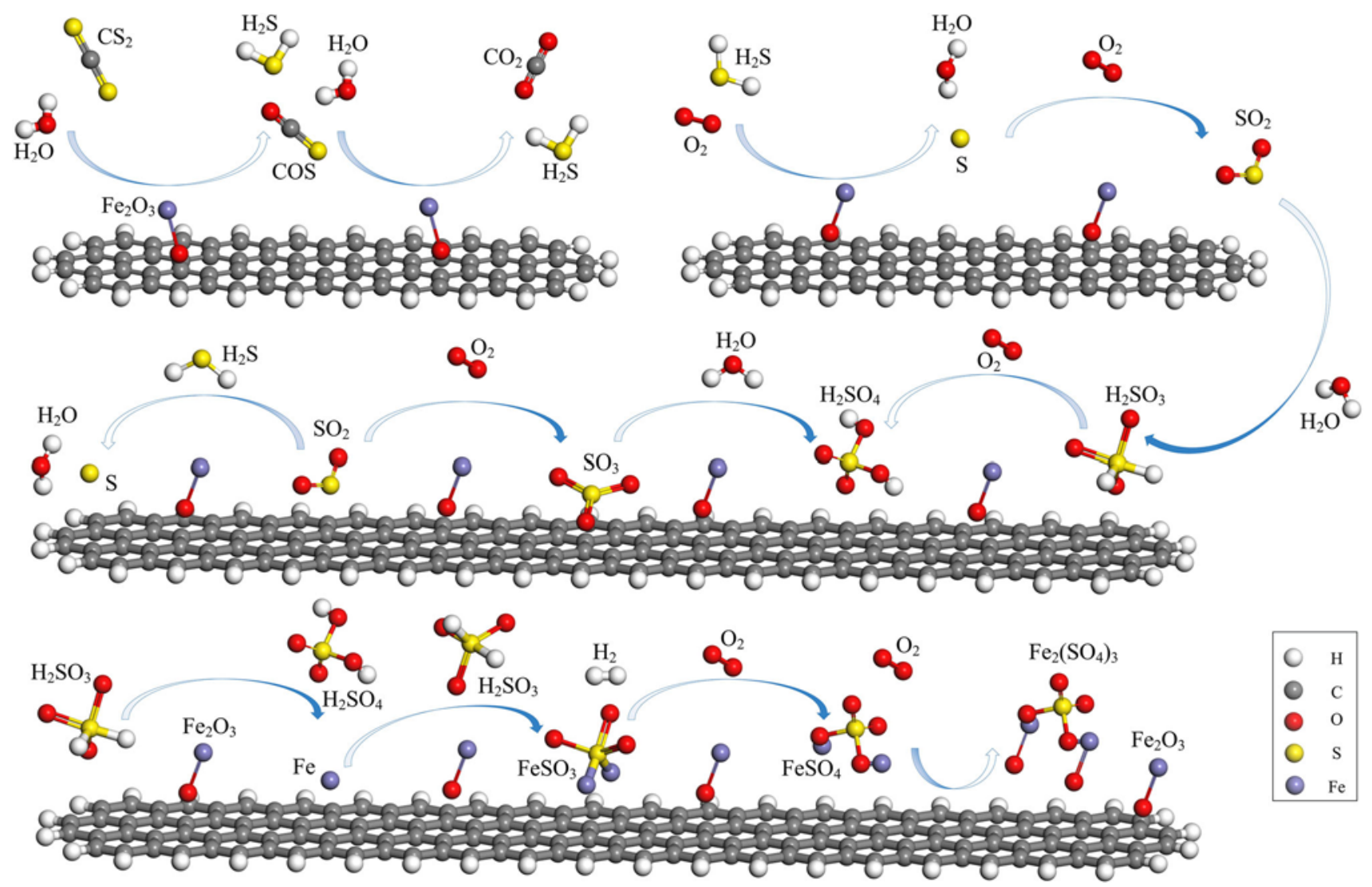

Figure 7. Deactivation mechanism of the simultaneous removal of $\mathrm{CS}_{2}$ and $\mathrm{COS}$. 
groups on the surface of the catalyst at 0 min (fresh catalyst). The increase of the $\mathrm{CO}_{2}$ molecule indicated that the hydrolysis reaction occurred. Meanwhile, the amount of $-\mathrm{C}=\mathrm{O}$ groups, $-\mathrm{COO}$ groups, $-\mathrm{CH}$ groups and $\mathrm{C}-\mathrm{OH}$ groups in the reaction were obviously higher than that at $0 \mathrm{~min}$ (fresh catalyst). It indicated that these functional groups mainly formed from the reaction process, especially by the interaction of metal oxide with $\mathrm{CO}_{2}$ and $\mathrm{H}_{2} \mathrm{O}$. The decreasing amounts of $\mathrm{H}_{2} \mathrm{O}\left(3495 \mathrm{~cm}^{-1}\right)$, the $\mathrm{C}-\mathrm{OH}$ groups $\left(1040 \mathrm{~cm}^{-1}\right.$, $\left.1065 \mathrm{~cm}^{-1}\right)$ and the $-\mathrm{CH}$ groups $\left(1155 \mathrm{~cm}^{-1}\right)$ indicate that these species were involved in the hydrolysis reaction. The increase of the $\mathrm{S}-\mathrm{O}$ groups $\left(815 \mathrm{~cm}^{-1}\right)$ indicates that sulphate was generated and accumulated on the catalyst. The bond energies of different chemical bonds are shown in Table S1. ${ }^{31-34}$ As seen, the $\mathrm{C}=\mathrm{O}$ bond energy is higher than that of $\mathrm{S}-\mathrm{O}$, and the bond energies of $\mathrm{C}-\mathrm{O}$ and $\mathrm{O}-\mathrm{H}$ are lower than that of $\mathrm{S}-\mathrm{O}$, which indicates that the $\mathrm{S}-\mathrm{O}$ bond may originate from $\mathrm{C}-\mathrm{O}$ and $\mathrm{O}-\mathrm{H}$. The decreasing amounts of -COO groups $\left(1435 \mathrm{~cm}^{-1}\right)$ supports the above assumption. Meanwhile, the $\mathrm{S}-\mathrm{O}$ groups are also derived from the direct oxidation of $\mathrm{H}_{2} \mathrm{~S}$ in the environment with $0.5 \%$ $\mathrm{O}_{2}$. According to these results, the formation of sulphate may be as follows: (a) $\mathrm{H}_{2} \mathrm{~S}+\mathrm{O}_{2} \rightarrow \mathrm{S}+\mathrm{H}_{2} \mathrm{O}$, (b) $\mathrm{S}+\mathrm{O}_{2} \rightarrow \mathrm{S}-\mathrm{O}$, (c) $-\mathrm{COO}+\mathrm{H}_{2} \mathrm{~S} \rightarrow-\mathrm{CH}+\mathrm{S}-\mathrm{O}$, (d) $\mathrm{C}-\mathrm{OH}+\mathrm{H}_{2} \mathrm{~S} \rightarrow-\mathrm{CH}+\mathrm{S}-\mathrm{O}$. Combined with the previous XPS results, the formation of sulphate and the decreasing and conversion of $\mathrm{Fe}_{2} \mathrm{O}_{3}$ are the main reasons for the deactivation of the catalyst.

\subsection{Deactivation mechanism}

On the basis of this work, the deactivation mechanism of the simultaneous removal of $\mathrm{CS}_{2}$ and COS is shown in Figure 7. Overall, the process includes two steps: the hydrolysis of $\mathrm{CS}_{2}$ and COS, and the oxidation of $\mathrm{H}_{2} \mathrm{~S}$. Initially, $\mathrm{COS}, \mathrm{CS}_{2}$ and $\mathrm{H}_{2} \mathrm{O}$ are adsorbed onto the catalyst's surface. $\mathrm{H}_{2} \mathrm{~S}$ and $\mathrm{CO}_{2}$ are then generated by $\mathrm{Fe}_{2} \mathrm{O}_{3}$ through $\mathrm{C}=\mathrm{S}$ bond cleavage and $\mathrm{S}-\mathrm{H}$ bond formation. The $\mathrm{O}_{2}$ molecule, the $\mathrm{C}-\mathrm{OH}$ groups, the $-\mathrm{COO}$ groups and $\mathrm{Fe}_{2} \mathrm{O}_{3}$ promote the oxidation of $\mathrm{H}_{2} \mathrm{~S}$. The generation of sulphate occupies the active sites and inhibits the active components of $\mathrm{Fe}_{2} \mathrm{O}_{3}$, which decreases the hydrolytic efficiency and leads to the deactivation of the catalyst.

\section{Conclusions}

In this study, the deactivation mechanism of the simultaneous catalytic hydrolysis of $\mathrm{COS}$ and $\mathrm{CS}_{2}$ over a $\mathrm{Fe}-\mathrm{Cu}-\mathrm{Ni} / \mathrm{MCSAC}$ catalyst was investigated with
SEM/EDS, XPS methods. On the basis of the SEM/EDS and XPS results, the reaction mechanism appears to include two steps: the hydrolysis of COS and $\mathrm{CS}_{2}$ and the oxidation of $\mathrm{H}_{2} \mathrm{~S}$. COS and $\mathrm{CS}_{2}$ can be catalytically hydrolysed to $\mathrm{H}_{2} \mathrm{~S}$, which is an intermediate product of $\mathrm{CS}_{2}$ hydrolysis, including COS. However, COS can be further hydrolysed to $\mathrm{H}_{2} \mathrm{~S}$, which could subsequently be oxidized to sulphate in the presence of $\mathrm{O}_{2}$. The catalytic hydrolysis of $\mathrm{CS}_{2}$ is achieved via alkaline groups and active components. When $\mathrm{O}_{2}$ was introduced into the system, the oxidation of $\mathrm{H}_{2} \mathrm{~S}$ occurred via $\mathrm{H}_{2} \mathrm{~S} \rightarrow$ $\mathrm{S} / \mathrm{RSOR} \rightarrow \mathrm{RSO}_{2} \mathrm{R} \rightarrow \mathrm{RSO}_{2} \mathrm{OR} \rightarrow \mathrm{SO}_{4}^{2-} /$ sulphate. Meanwhile, the contents of $\mathrm{SO}_{4}^{2-} /$ sulphate increased during the reaction, and they could occupy the activity sites on the catalyst's surface. Additionally, the alkaline groups and active components were removed, which caused the deactivation of the catalysts. In-situ DRIFTS experiments indicated that the formation of sulphate may occur as follows: (a) $\mathrm{H}_{2} \mathrm{~S}+\mathrm{O}_{2} \rightarrow \mathrm{S}+\mathrm{H}_{2} \mathrm{O}$, (b) $\mathrm{S}+\mathrm{O}_{2} \rightarrow \mathrm{S}-\mathrm{O}$, (c) $-\mathrm{COO}+\mathrm{H}_{2} \mathrm{~S} \rightarrow-\mathrm{CH}+\mathrm{S}-\mathrm{O}$, (d) $\mathrm{C}-\mathrm{OH}+\mathrm{H}_{2} \mathrm{~S} \rightarrow-\mathrm{CH}+\mathrm{S}-\mathrm{O}$. The $\mathrm{C}-\mathrm{OH}$ groups, $-\mathrm{COO}$ groups and the $\mathrm{O}_{2}$ molecule played important roles in the deactivation of the catalyst.

\section{Supplementary Information}

Figures S1-S4 are available as Supplementary Information at www.ias.ac.in/chemsci.

\section{Acknowledgements}

This work was supported by the National Natural Science Foundation of China (51408282, 21667015), China Scholarship Council (201508530017, 201608530169, 201608740 011) and the Analysis and Testing Foundation of Kunming University of Science and Technology.

\section{References}

1. Leman L J, Orgel L E and Ghadiri M R 2006 Amino acid dependent formation of phosphate anhydrides in water mediated by carbonyl sulfide J. Am. Chem. Soc. 12820

2. Sun X, Ning P, Tang X L, Yi H H, Li K, He D, Xu X M, Huang B and Lai R Y 2014 Simultaneous catalytic hydrolysis of carbonyl sulfide and carbon disulfide over $\mathrm{Al}_{2} \mathrm{O}_{3}-\mathrm{K} / \mathrm{CAC}$ catalyst at low temperature J. Energy Chem. 23221

3. Chowanietz V, Pasel C, Eckardt T, Siegel A and Bathen D 2016 Formation of carbonyl sulfide (COS) on different adsorbents in natural gas treatment plants Oil Gas Eur. Mag. 4282

4. Zhao S Z, Yi H H, Tang X L, Gao F Y, Yu Q J, Zhou Y S, Wang J G, Huang Y H and Yang Z Y 2016 Enhancement effects of ultrasound assisted in the synthesis of 
NiAl hydrotalcite for carbonyl sulfide removal Ultrason. Sonochem. 32336

5. Qiu J, Ning P, Wang X Q, Li K, Liu W, Chen W and Wang L L 2014 Removing carbonyl sulfide with metalmodified activated carbon Front. Env. Sci. Eng. 1011

6. Kuznetsov D L, Filatov I E and Uvarin V V 2016 Processes of carbon disulfide degradation under the action of a pulsed corona discharge Tech. Phys. Lett. 42822

7. Yegiazarov Y, Clark J, Potapova L, Radkevich V, Yatsimirsky V and Brunel D 2005 Adsorption-catalytic process for carbon disulfide removal from air Catal. Today $\mathbf{1 0 2} 242$

8. Huang H M, Young N, Williams B P, Taylor S H and Hutchings G 2006 High temperature COS hydrolysis catalysed by $\gamma-\mathrm{Al}_{2} \mathrm{O}_{3}$ Catal. Lett. 110243

9. Liu Y C, He H and Ma Q X 2008 Temperature dependence of the heterogeneous reaction of carbonyl sulfide on magnesium oxide J. Phys. Chem. A 1122820

10. Rhodes C, Riddel S A, West J, Williams B P and Hutchings G J 2000 The low-temperature hydrolysis of carbonyl sulfide and carbon disulfide: a review Catal. Today 59443

11. Ning $\mathrm{P}, \mathrm{Yu} \mathrm{L}$ L, Yi H H, Tang $\mathrm{X}$ L, Li H, Wang H Y and Yang L N 2010 Effect of Fe/Cu/Ce loading on the coal-based activated carbons for hydrolysis of carbonyl sulfide J. Rare Earth 28205

12. Zhu Y Y, Kolar P, Shah S B, Cheng J J and Lim P K 2016 Avocado seed-derived activated carbon for mitigation of aqueous ammonium Ind. Crop. Prod. 9234

13. He Q, Dai J L, Zhu L, Xiao K J and Yin Y R 2016 Synthesis and lead absorption properties of sintered activated carbon supported zero-valent iron nanoparticle J. Alloy. Compd. $\mathbf{6 8 7} 326$

14. Balsamo M, Cimino S, Falco G D, Erto A and Lisi L $2016 \mathrm{ZnO}-\mathrm{CuO}$ supported on activated carbon for $\mathrm{H}_{2} \mathrm{~S}$ removal at room temperature Chem. Eng. J. 304399

15. Li K, Song X, Ning P, Yi H H, Tang X L and Wang C 2014 Energy utilization of yellow phosphorus tail gas: simultaneous catalytic hydrolysis of carbonyl sulfide and carbon disulfide at low temperature Energy Technol. 3 136

16. Ning P, Li K, Yi H H, Tang X L, Peng J H, He D, Wang H Y and Zhao S Z 2012 Simultaneous catalytic hydrolysis of carbonyl sulfide and carbon disulfide over modified microwave coal-based active carbon catalysts at low temperature J. Phys. Chem. C 11617055

17. Yi H H, Li K, Tang X L, Ning P, Peng J H, Wang C and He D 2013 Simultaneous catalytic hydrolysis of low concentration of carbonyl sulfide and carbon disulfide by impregnated microwave activated carbon at low temperatures Chem. Eng. J. 230220

18. Li K, Liu G, Gao T Y, Lu F, Tang L H, Liu S J and Ning P 2016 Surface modification of Fe/MCSAC catalysts with coaxial cylinder dielectric barrier discharge plasma for low-temperature catalytic hydrolysis of $\mathrm{CS}_{2}$ Appl. Catal. A $\mathbf{5 2 7 1 7 1}$
19. Guo H B, Tang L H, Li K, Ning P, Sun X, Liu G, Bao S Y, Zhu T T, Jin X, Duan Z Y and Li Q S 2016 The hydrolysis mechanism and kinetic analysis for COS hydrolysis: A DFT study Russ. J. Phys. Chem. B 10427

20. Yi H H, Zhao S Z, Tang X L, Song C Y, Gao F Y, Zhang B W, Wang Z X and Zuo Y R 2014 Low-temperature hydrolysis of carbon disulfide using the $\mathrm{Fe}-\mathrm{Cu} / \mathrm{AC}$ catalyst modified by non-thermal plasma Fuel 128268

21. Li X H, Ren S J, Wei X G, Zeng Y, Gao G W, Y. Ren, Zhu J, Lau K C and Li W K 2014 Concerted or stepwise mechanism? New insight into the water-mediated neutral hydrolysis of carbonyl sulfide J. Phys. Chem. A 1183503

22. Wang H Y, Yi H H, Tang X L, Yu L L, He D, Zhao S Z and K Li 2013 Reactivation of CoNiAl calcined hydrotalcitelike compounds for hydrolysis of carbonyl sulfide Ind. Eng. Chem. Res. 529331

23. George Z M 1974 Kinetics of cobalt-molybdatecatalyzed reactions of $\mathrm{SO}_{2}$ with $\mathrm{H}_{2} \mathrm{~S}$ and $\mathrm{COS}$ and the hydrolysis of COS J. Catal. 32261

24. Akimoto M and Lana I G D 1980 Role of reduction sites in vapor-phase hydrolysis of carbonyl sulfide over alumina catalysts J. Catal. 6284

25. Ju S 1998 Hydrolysis of carbonyl sulfide and carbon disulfide over alumina based catalysts I. Study on activities of $\mathrm{COS}$ and $\mathrm{CS}_{2}$ hydrolysis J. Nat. Gas Chem. 7 16

26. Hoggan P E, Aboulayt A, Pieplu A, Nortier P and Lavalley J C 1994 Mechanism of COS hydrolysis on alumina J. Catal. 149300

27. Wilson C and Hirst D M 1995 High-level ab initio study of the reaction of OCS with $\mathrm{OH}$ radicals J. Chem. Soc. Faraday T. 91793

28. Sakanishi K, Wu Z H, Matsumura A, Saito I, Hanaoka T, Minowa T, Tada M and Iwasaki T 2005 Simultaneous removal of $\mathrm{H}_{2} \mathrm{~S}$ and COS using activated carbons and their supported catalysts Catal. Today 10494

29. Aboulayt A, Mauge F, Hoggan P E and Lavalley J C 1996 Combined FTIR, reactivity and quantum chemistry investigation of COS hydrolysis at metal oxide surfaces used to compare hydroxyl group basicity Catal. Lett. 39 213

30. Li W, Peng J, Zhang L, Yang K, Xia H, Zhang S and Guo S H 2008 Preparation of activated carbon from coconut shell chars in pilot-scale microwave heating equipment at $60 \mathrm{Kw}$ Waste Manage. 29756

31. Luo Y R 2007 Comprehensive Handbook of Chemical Bond Energies (Boca Raton: CRC Press)

32. Cottrell T L 1958 The Strengths of Chemical Bonds $2^{\text {nd }}$ edn. (London: Butterworths Scientific Publications)

33. U.S. Dept. of Commerce 1970 National standard reference data series, National Bureau of Standards, Washington.

34. Benson S W 1965 III-Bond energies J. Chem. Educ. 42 502 